\title{
Cinema de intervenção: memória, cumplicidade e incorporação do documentário como linguagem importante ao movimento operário brasileiro dos anos 1970 e 1980
}

DOI: 10.1590/1809-58442017116

\section{Maria Alice Campagnoli Otre}

(Universidade de Marília, Pró-Reitoria de Graduação, Curso de Comunicação Social - Publicidade e Propaganda. Marília - SP, Brasil)

CORRÊA, Marcos. Filmar operários: registro e ação política dos cineastas durante a ditadura militar no Brasil. Curitiba: Appris, 2016. 351p.

Fruto de uma tese de doutorado, o livro Filmar operários: registro e ação política dos cineastas durante a ditadura militar no Brasil, de Marcos Corrêa, lançado em 2016 pela Editora Appris, tece história, cinema e comunicação alternativa no contexto do movimento popular/sindical. De maneira consistente, sem abandonar a leitura prazerosa e fluida em suas 350 páginas, o texto não se reveste de um

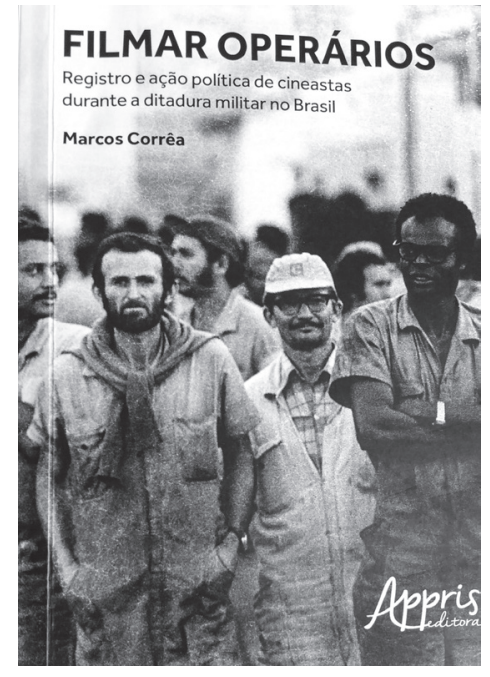
academicismo que distancia o leitor interessado no tema; da mesma forma que não menospreza o cuidado metodológico e científico com o qual o autor analisa a temática, por meio da análise de conteúdo.

A obra analisa nove documentários dos anos 1970 e 1980 que fugiram do modo de produção cinematográfico tradicional e exploraram o protagonismo coletivo e as demandas específicas dos segmentos retratados.

Dividido em quatro capítulos, o livro traz em sua primeira parte alguns conceitos que fundamentam a relação entre o cinema e as causas operárias, abordando a história, o protagonismo da igreja católica em sua vertente libertária (principalmente, representada pelas Comunidades Eclesiais de Base - CEBs - em sua relação com o movimento sindical do Grande $\mathrm{ABC}$ ) e a origem e importância da imprensa sindical para o contexto analisado na obra.

Os outros três capítulos são organizados de forma a verificar as hipóteses levantadas pelo pesquisador, uma em cada capítulo, conforme veremos. 
No capítulo 2, sob o título "Operários e cineastas: como o documentarista restabelece discursos políticos sobre o operariado brasileiro”, Corrêa verifica uma primeira hipótese envolvendo quatro filmes que, segundo ele, "deslocam o operário do papel de coadjuvante para o elemento central da narrativa fílmica” (p.28).

São analisados documentários que se debruçam sobre a temática do operário brasileiro: Operários da Volkswagen (Wolf Gauer e Jorge Bodanzky, 1974), Acidente de Trabalho (Renato Tapajós, 1977), Trabalhadoras Metalúrgicas (Renato Tapajós e Olga Futemma, 1978) e Chapeleiros (Adrian Cooper, 1981). Segundo o pesquisador, esses filmes inauguram uma forma de representar conceitos e imagens da classe operária e que passam longe de discussões panfletárias e, ainda, se posicionam politicamente diante daquilo que retratam; seja por opção própria do realizador, seja pelo estabelecimento de um vínculo institucional com o qual o cineasta simpatiza.

O capítulo 3, intitulado "Militância e embate: o cineasta diante do outro em greve", selecionou filmes que tratassem diretamente do tema greve buscando compreender de que modo filmes e cineastas se envolveram com as bases trabalhadoras, registrando momentos importantes e que supunham compreensão do contexto envolvido e dos limites e necessidades da realização cinematográfica. São aqui analisados os documentários Braços Cruzados, Máquinas Paradas (Roberto Gervits/Sergio Segall, 1979), Greve! e Trabalhadores: Presente! (João Batista de Andrade, 1979). As análises demonstraram o ineditismo e a importância da presença e envolvimento direto do cineasta durante o percurso da realização em alguns filmes, a postura independente e interventiva do cineasta possibilitou, segundo Corrêa, expor as contradições internas do próprio movimento como recurso estratégico para despertar nos trabalhadores a consciência de seus limites e problemas (p.322).

O quarto e último capítulo, "O diálogo entre memória e ação política: a reconstrução do passado pela lente do cineasta”, trouxe à tona uma revisão que cineastas e movimentos fazem de sua trajetória. Os filmes analisados foram Os Queixadas (Rogério Corrêa, 1978), que convida os grevistas da fábrica de cimento de Perus (movimento que vai de 1962 a 1969) para reconstruir o momento com base em suas memórias, como forma de representação do que viveram e Linha de Montagem (Renato Tapajós, 1982), que investiga a gênese do movimento sindical de São Bernardo do Campo por meio da memória dos responsáveis pelo movimento e do protagonismo cinematográfico como parte do processo. Seria, como define o pesquisador/autor, "o resgate de uma memória adormecida com a intenção de que interfira no presente” (p.271).

Com um recorte e olhar ainda não explorados academicamente sobre esse momento histórico e produções fílmicas, o livro é de grande importância aos pesquisadores da comunicação popular e alternativa, da imprensa sindical e dos que se dedicam às análises de audiovisuais, pelo cuidado e competência com as quais o autor as desenvolve explorando os 
ângulos de tomada, a narrativa, o roteiro, a constituição das cenas de maneira imbricada aos processos históricos que se desenvolviam paralelamente às realizações cinematográficas. Além disso, para dar mais clareza ao leitor a respeito das análises realizadas, a obra conta com 136 imagens que se debruçam sobre os detalhes para os quais o autor pretende chamar a atenção.

Corrêa finaliza a obra destacando a importância desses documentários analisados para a posterior institucionalização no meio sindical do audiovisual (abrindo espaço para futuras discussões sobre a criação de instituições como a TV dos Trabalhadores - TVT) que passaria a atender demandas internas e externas por visibilidade, por documentação, porém, refletindo um posicionamento oficial, com processo de produção hierarquizado, e que se afasta das posturas e do relacionamento travado entre cineastas e base operária nas obras abordadas no livro.

Por fim, Filmar operários é um convite a uma viagem histórica pela militância do movimento operário brasileiro que não está tão distante assim de nossas discussões e realidade. Além disso, é também um convite aos cineastas e produtores fílmicos para que repensem seus papéis enquanto coautores da história por meio de olhares que podem invisibilizar ou garantir protagonismo aos setores por eles retratados, principalmente na vertente da comunicação alternativa.

\section{Maria Alice Campagnoli Otre (autora da resenha)}

Doutora e mestre pela Universidade Metodista de São Paulo (UMESP), com pesquisas enfocando a comunicação popular, alternativa e comunitária e membro do Núcleo de Estudos em Comunicação Comunitária e Local - Comuni, do Poscom/Umesp, desde 2007. Possui graduação em Comunicação Social - Jornalismo, pela Universidade de Marília, e graduação em Tecnologia em Produção Publicitária, pela Unigran. É professora da Universidade de Marília, atuando no curso de Comunicação Social - Publicidade e Propaganda. E-mail: maliceotre@gmail.com

Recebido em: 31.01.2017 Aceito em: 06.02.2017 